\title{
Beschermingsconstructies, structuurregime en ondernemingswaarde
}

\author{
Dr. L.R.T. van der Goot en Dr. R.H. van het Kaarl
}

\section{Inleiding}

De discussie over het verschijnsel beschermingsconstructies van ondernemingen genoteerd aan de Amsterdamse Effectenbeurs is in een stroomversnelling gekomen. Dit blijkt bijvoorbeeld uit de brief over beschermingsconstructies van de Minister van Financiën aan de Tweede Kamer (1996) en hel daarop ansluitende wetsontwerp over beschermingsconstructies dat in december 1996 aan de Raad van State is aangeboden voor advies alsmede uit het rapport van de Commissie Peters (1997), en de reacties die dat heeft opgeroepen.

De merendeels buitenlandse publicaties over de effecten die beschermingsconstructies hebben op de wiarde van een ondememing leveren geen eenduidig beeld op. Zie Bosveld en Goedbloed ( 1996) voor een overzicht. Bovendien kan het buitenlandse onderzoek niet zonder meer van toepassing verklaard worden op de Nederlandse situatie. Het institutionele kader met betrekking tot de effectenmarkt in bijvoorbeeld Duitsland, Engeland, Frankrijk en de Verenigde Staten wijkt af van dat van Nederland: het toezicht in die landen is in handen van organen die onafhankelijk zijn van de beurs. Versterking van het onafhankelijk toezicht in Nederland is overigens wel in voorbereiding.

Een ander verschil is dat de in ons land gehanteerde beschermingsconstructies veelal van meer juridische aard zijn dan hun buitenlandse soortgenoten. Juridische beschermingsconstructies worden gekenmerkt door het principe dat 'één alandeel, één stem' niet geldt dan wel dat bepaalde categorieën kapitaalverschaffers helemaal geen stemrechten hebben. Bovendien hebben deze constructies als kenmerk dat invoering ervan niet gepaard gaat met betalingen, afgezien van advocaal- en notariskosten en dergelijke. De belangrijkste juridische constructies zijn certitice- ring in combinatie met een $\mathrm{X} \%$-regeling, de bevoegdheid preferente beschermingsaandelen uit te geven en de verschillende soorten van prioriteitsrechten. Tot de categorie juridische beschemingsconstructies behoren ook de 'poison pill'- en 'crown jewel'-constructies. Eerstgenoemde zadelt de onderneming op met hoge kosten, laatstgenoemde ontdoet de onderneming van zijn meest winstgevende onderdelen. Ook het structuurregime kan worden beschouwd als een juridische beschermingsconstructie.

Tegenover de juridische staan de economische beschermingsconstructies, waarbij alle aandeelhouders gelijke (stem)rechten hebben. Invoering van economische beschermingsconstructies gaat wel gepaard met betalingen: denk aan de uitgifte van financieringsprefs.

Een derde punt van verschil is dat in ons land meestal gebruikgemaakt wordt van meerdere beschermingsconstructies per onderneming.

Dit artikel heeft twee doelstellingen. De eerste is dat het de verschillende beschermingsconstructies die worden aangetroffen bij ondernemingen op de Amsterdamse Effectenbeurs analyseert en indeelt. Naast de hiervoor al genoemde tweedeling in

Dr. L.R.T. van der Goot heeft aan de Erasmus Universiteit Rotterdam het doctoraal examen Economie en het kandidaatsexamen Nederlands Recht behaald. Hij is op 3 september j.l. gepromoveerd op het onderwerp de waardering van nieuwe emissies en informatiekwaliteit in emissieprospectussen.

Dr. R.H. van het Kaar behaalde in 1988 zijn doctoraal examen Economie en promoveerde in 1993 op het onderwerp medezeggenschap bij fusie en ontvlechting. Hij werkt als senior onderzoeker bij het Hugo Sinzheimer Instituut

Beide auteurs zijn verbonden aan de Vakgroep Accountancy en Recht van de Faculteit der Economische Wetenschappen en Econometrie van de Universiteit van Amsterdam. 
juridische en economische beschermingsconstructies kunnen we nog 1 wee soorten constructies onderscheiden. Daarvan kan één categorie aangemerkt worden als anti-overnameconstructies. Deze zijn met name bedoeld om onvriendelijke overnames te blokkeren en richten zich daarmee vooral tegen potentiële aandeelhouders. De andere categorie kenmerkt zich vooral door de belenmmering of uitschakeling van het disciplineringsmechanisme van de kant van aandeelhouders. Dit treft met name de bestaande aandeelhouders die invloed willen uitoefenen op de dagelijkse gang van zaken bij een beursgenoteerde onderneming. Het laatste aspect wordt onder meer benadrukı door Boot (1994).

De tweede doelstelling van het artikel is een nader onderzoek naar de vraag of de gehanteerde indeling in anti-overname en anti-disciplineringsmechanismen zich ook uit in een verschil in associatie tussen de betreffendc mechanismen en de waardering van de onderneming. Hierbij is een tweedeling gemaakt in ondernemingen met en zonder structuurregime. De reden valn de speciale aandacht voor het structuurregime in dit artikel is dat het structuurregime noch door de Amsterdamse Effectenbeurs, noch door de Minister van Financiën, noch door de Commissie Peters die de structuurregeling uitdrukkelijk buiten beschouwing laat, wordt alangemerkt als beschermingsconstructie, terwijl het structuurregime toch wel als zodanig fungeert. Zie over het structuurregime verder paragraaf 2 .

De opbouw van het artikel is als volgt. Paragraaf 2 gaat nader in op de structuurregeling. In paragraaf 3 worden de verschillende constructies geanalyseerd naar twee onderscheiden effecten die zij (kunnen) hebben: bescherming in geval van de dreiging van een vijandige overname enerzijds en gevolgen voor de mogelijkheid tot disciplinering van het management anderzijds. In paragraaf 4 worden hypothesen geformuleerd over het effect van beschermingsconstructies op de waarde van de onderneming. Paragraaf 5 geeft een beschrijving van het datamateriaal en de gehanteerde methodologie. In paragraaf 6 presenteren wij de resultaten van het empirisch onderzoek. Het artikel besluit met een samenvatting en conclusies.

\section{Het structuurregime nader beschouwd}

\subsection{Gelijkwaardigheid van arbeid en kapitaal}

De achterliggende gedachte achter invoering van de structuurregeling was de toekenning van een gelijkwaardige positie aan kapitaal en arbeid in grote vennootschappen. De raad van commissarissen is tot het machtigste orgaan gemaakt: zij krijgt de bevoegdheid tot benoeming en ontslag van bestuurders en tol vaststelling van de jaarrekening en een recht van goedkeuring ten aanzien van vrijwel alle belangrijke besluiten van het bestuur. Samenstelling van de raad van commissarissen vindt plaats door middel van coöptatie. De invloed van kapitaal (aandeelhouders) en arbeid (ondernemingsraad) heeft gestalte gekregen in het recht van aanbeveling en bezwaar bij de (her)benoeming van commissarissen: de algemene vergadering. de ondernemingsrad en het bestuur (sic) kunnen aan de raad van commissarissen personen voor benoeming lot commissaris aanbevelen (art. 2:158 BW en art. 2:268. vierde lid $\mathrm{BW}$ ) en de algemene vergadering en de ondernemingsralad kunnen tegen een voorgenomen (her)benoeming bezwalar maken (idem, zesde lid). Bindende voordracht van commissarissen of bestuurders is uitdrukkelijk verboden (zie de slotzin van art. 2:158 lid $2 \mathrm{BW}$ en de tweede zin van art. 2:162 BW), omdat dat in strijd is met de gedachte achter de regeling.

\subsection{De volledige structuuregeling als beschermingsconstructic}

Een niet-bedoeld bijverschijnsel van het volledig structuurregime is dat het tegelijk fungeert als bescherming tegen een vijandige overname. Immers, bezil van de meerderheid van de aandelen geeft nog geen zeggenschap, omdat de kernbevoegdheden. in het bijzonder de bevoegdheid om de bestuurders te benoemen en te ontslaan, in handen van de raad van commissarissen zijn. Belangrijk kenmerk van hel structuurregime is bovendien dat het systeem een permanente vermindering van de zeggenschap van aandeelhouders tot gevolg heeft, in tegenstelling tot bijvoorbeeld de bescherming tegen een overval door middel van de uitgifte van beschermingsprefs. Het fungeert dus niet alleen als effectief anti-overname-, maar ook als anti-disciplineringsmechanisme.

Onder de meeste Nederlandse vennootschapsjuristen lijkt de structuurregeling als zodanig niet omstreden. ${ }^{2}$ Wel is kritiek uitgeoefend op 'oneigenlijke' toepassing van de regeling. Daarmee wordt gedoeld op vennootschappen die hun statuten niet wijzigen hoewel op grond van de wet eigenlijk 
vrijstelling of toepassing van het verzwakte regime op zijn plaats zou zijn. In de literatuur is geopperd om ann voortzenting van het volledig regime, nadat dit niet meer verplicht van toepassing is. de cis te stellen dat die voortzetting berust op een expliciet besluit van de AvA. 'Oligarchische regelingent kunnen echter een vrijwel onoverkomelijke barrière vormen voor een dergelijk besluil wanneer de structuurregeling van het begin af aan vrijwillig van toepassing is verk laard. Weliswalar zou men kunnen betogen dat alan invoering van die regeling op vrijwillige basis een expliciel besluit van de algemene vergadering van alandeelhouders ten grondslitg heeft gelegen ('ze zijn er zelf bij geweest"). maar de samenstelling van dic AvA kan inmiddels ingrijpend zijn veranderd.

\subsection{Het structuntregime ter discussie}

Bezien door een Angelsaksische bril is het structuurregime een uiterst merkwalardige construclie, maar in Nederland is de regeling, waarbij verschillende stakeholders - en niet alleen iandeelhouders - een belangrijke stem hebben in de vennootschalp en de dararmee verbonden onderneming. breed geaccepteerd. Ook de Commissie Peters ziet geen reden voor herziening van de wellelijke regeling voor grote vennoonschappen. Het is vooral het systeem van gecontroleerde coöptatie wall onder vuur ligt. omdat het zou leiden tol gebrek alan disciplinering van het management. De oplossing zou dan gezocht moeten worden in het (deels) Ioslaten van dit systeem. bijvoorbeeld door directe benoeming van (of een bindende voordrachu voor) een deel van de commissarissen door direct belanghebbenden en coöplatie van de overige commissarissen. Een van de voordelen van een wijziging in die richting is dat de verschillende effecten die het structuuregi- me nu heeft - zowel hel ondergraven van de disciplinering van het management als bescherming tegen een vijandige overval - als het ware uit elkaar worden getrokken: wel (toename van) de disciplinering vin het management onder behoud van hel beschermingskarakler (los van de vraag of dat laatste als wenselijk wordt beschouwd).

\section{De verschillende effecten van beschermingsconstructies}

De beursigang van een onderneming is een gelegenheid bij uitske om het effect vin beschermingsconstructies op ondernemingswitarde te onderzoeken vanwege het feit dat het management voor een dilemma stalat. Aan de ene kint geldt. dat de meerderheid van de emitterende ondernemingen relatief onbekend is bij de beleggers. Mel name bij niet-genoteerde ondernemingen speelt het probleem van de ongelijke verdeling van informatie tussen de beleggers en de managers van de emittent. Het management zal er veel alan gelegen zijn de beleggers van de goede $k$ waliteiten van de ondememing te overtuigen om een zo hoog mogelijke emissiekoers le bewerkstelligen. Aan de andere kant kunnen conmerciële belangen de ondernemingsleiding beletten een al te grote openheid te betrachten. wat nadelig uipatht voor de emissiekoers.

Een onderneming die "open" gaat. stelt zich bloot aan de invloed van de effectenmark1. Bij een beursintroductie zal het management van de emittent derhalve een keuze moeten maken met betrekking tot hel al dan niet introduceren van beschermingsconstructies. walardoor de ondernemingsleiding zich in meerdere of mindere mate alschermt van de effectenmarkt.

Tabel I geeft een overzicht van de beschermingsconstructies, die wij hebben onderzocht. Hieronder zullen we deze kort bespreken. De

Tabel 1: Het voorkomen van vijf verschillende beschermingsconstructies van alle 74 ondernemingen die in de periode $198.3-1992$ cen eerste notering hebben verkregen op de Ansterdamse Effectenbeurs

\begin{tabular}{|c|c|c|c|c|}
\hline Beschermingseonstructices $(n=74)$ & Ondernemingen me' $B C^{\prime}$ & t/ & Ondernemingen zonder $B C$ & $\%$ \\
\hline Structuurregime & 31 & +2 & +3 & 58 \\
\hline Prioriteitsaandelen & 37 & 50 & 37 & 50 \\
\hline Preferente atundelen & 36 & 49 & 38 & 51 \\
\hline Certificatten van gewone atandelen & 31 & 42 & +3 & 58 \\
\hline X\%-regel & 11 & 15 & 63 & 85 \\
\hline
\end{tabular}

${ }^{\prime} \mathrm{BC}=$ de beschemingsconsuructic genoemd op de regel (structumregime, prioriteitsitandelen enz.) 


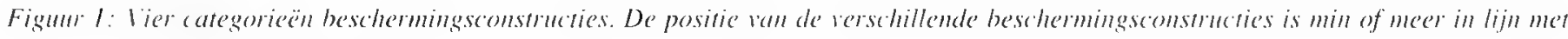
de trikomsten l'all rabe' 2

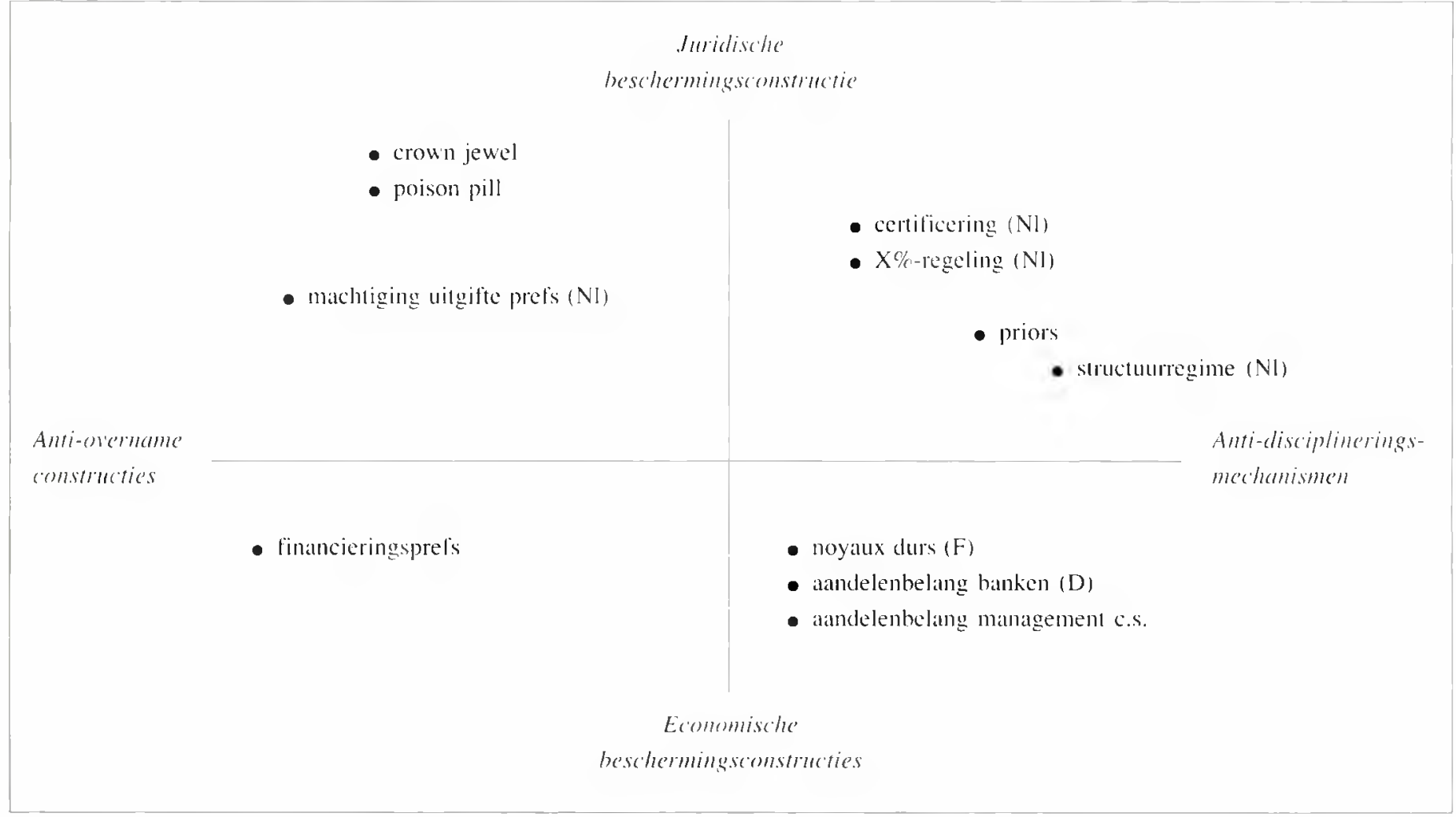

bevoegdheid van het bestuur om preferente alandelen uit te geven heeft als doel het alweren van een vijandige overval. De disciplinering door potentiële aandeelhouders wordt datarmee verzwatkt of onmogelijk gemaakt: alan de disciplinering door de bestaande aandeelhouders wordt in wezen niel afgedain. De mogelijkheden om dit instrument toe te passen zijn inmiddels ingeperkt als gevolg van het tussen de beurs en de VEUO gesloten compromis tot beperking van dergelijke constructies (Bijlage X van het Fondsenreglement).

Prioriteitsaandelen hebben een permanente vermindering van de invloed van alandeelhouders tot gevolg. Belangrijke bevoegdheden van de algemene vergadering van aandeelhouders als benoeming van bestuurders gebonden aan voorstellen van de houders van prioriteitsaandelen. ${ }^{5}$ Weliswaar kan een dergelijke bindende voordracht worden doorbroken. maar daartoe is vereist een besluit met twee derde van de stemmen der aandeelhouders die ten minste de helft van het geplaatste kapitaal moeten vertegenwoordigen. ${ }^{6}$

Ook besluiten tot statutenwijziging worden veelal afhankelijk gemaakt van een voorstel van de houders van prioriteitsaandelen. Er zijn nauwe- lijks grenzen gesteld aan wie houder van prioriteitsaandelen mogen zijn. Bijlage $X$ van het Fondsenreglement bepaalt slechts dat bestuurders van de vennootschap niet (rechtstreeks of middellijk) meer dan de helft van de prioriteitsalandelen in bezil mogen lebben.

Een derde vorm van bescherming/afscherming is certificering van alandelen in combinatie met de $X \%$-regel (geen enkele aandeelhouder met uitzondering van de Stichting Administrattiehantoor ( $\mathrm{Ak}$ ) mag meer dan $X \%$ van de aandelen in bezit hebben). Als gevolg van de certificering hebben de kapitaalverschaffers geen stemrecht; dat berust bij het Ak, dal de aandelen houdt. Het Ak dienı zich. op grond van de genoemde Bijlage X. bij de uitoefening van het stemrecht te richten naar het belang van de uitgevende instelling. de met halar verbonden onderneming en alle dairbij betrokkenen. De meerderheid van het stemrecht in het bestuur van het $\mathrm{Ak}$ moet berusten bij personen die niet verbonden zijn met de uitgevende instelling.

Figuur I brengt het onderscheid tussen de verschillende calegorieën beschermingsconstructies in beeld. Boven de horizontale as zijn de juridische 
Tabel 2: Tweezijdige t-toetsen van drie maatstaven voor ondernemingswaarde en telkens één beschermingsconstructie van de ondernemingen die in de periode 1983-1992 een eerste notering verkregen hebben op de Amsterdamse Effectenbeurs

\begin{tabular}{|c|c|c|c|c|c|c|c|c|c|}
\hline \multirow[b]{2}{*}{$\begin{array}{l}\text { Beschermings- } \\
\text { constructie }(n=74)\end{array}$} & \multicolumn{3}{|c|}{$\begin{array}{c}\text { Emissiekoersen/winst per uandeel } \\
(\text { PE ratio })\end{array}$} & \multicolumn{3}{|c|}{$\begin{array}{c}\text { Emissiekoers/eigen vermogen per } \\
\text { aandeel }(P B \text { ratio) }\end{array}$} & \multicolumn{3}{|c|}{$\ln ($ Enissiewaarde $)$} \\
\hline & $\begin{array}{l}\text { geniddelde } \\
\text { met } B C^{l}\end{array}$ & $\begin{array}{l}\text { gemiddelde } \\
\text { zonder } B C^{\prime}\end{array}$ & t-waarde & $\begin{array}{l}\text { geniddelde } \\
\text { met } B C\end{array}$ & $\begin{array}{l}\text { gemiddelde } \\
\text { zonder } B C\end{array}$ & t-waarde & $\begin{array}{r}\text { gemiddelde } \\
\text { met } B C\end{array}$ & $\begin{array}{l}\text { gemiddelde } \\
\text { zonder } B C\end{array}$ & t-watrde \\
\hline Structuurregime & 11,76 & 16,53 & $-2,15 * * *$ & 3,21 & 7,68 & $-319 * * *$ & 4,86 & 4,34 & 1.48 \\
\hline Prioriteitsaandelen & 16.18 & 12,28 & $1,77 *$ & 7,07 & 4,11 & $2,09 * *$ & 4,18 & 5,02 & $-2.54 * *$ \\
\hline $\begin{array}{l}\text { Preferente aandelen } \\
\text { Certificaten van }\end{array}$ & 15.15 & 13,27 & 0,84 & 5,56 & 5.70 & $-0,10$ & 4,83 & 4,37 & 1.33 \\
\hline gewone aandelen & 12,54 & 15.50 & $-1,32$ & 3,38 & 7,35 & $-2,85^{* *}$ & 4,36 & 4,77 & -1.19 \\
\hline X\%-regel & 11,84 & 14,62 & $-0,89$ & 2.87 & 6,11 & -1.62 & 4.40 & 4,63 & $-0,46$ \\
\hline
\end{tabular}

beschermingsconstructies gesitueerd, eronder de economische beschermingsconstructies. Verder staan links van de verticale as de anti-overname constructies en rechts ervan de anti-disciplineringsconstructies. De indeling in de figuur is een kwalitatieve, met daarbij de aantekening dat - voorzover van toepassing - rekening is gehouden met de uitkomsten van de T-toetsen in tabel 2 . Overigens geldt, dat anti-disciplineringsconstructies tevens werkzaam zijn als anti-overnameconstructies, terwijl het omgekeerde niet altijd opgaat.

\section{De hypothesen}

Zoals hiervoor is uiteengezet kunnen we beschermingsconstructies indelen al naar gelang hun invloed op de waarde van de onderneming. Het valt te verwachten dat economische beschermingsconstructies minder invloed op de ondernemingswaarde hebben dan de juridische. Immers, de onderneming verkrijgt een economische beschermingsconstructie tegen betaling, terwijl in geval van invoering van een juridische beschermingsconstructie aan de beleggers zeggenschap wordt ontnomen zonder (geldelijke) tegenprestatie. Dit wordt bevestigd door bijvoorbeeld Jarrell en Poulsen (1987). Zij vinden dat de invoering van een economische beschermingsconstructie nauwelijks invloed heeft op de ondernemingswaarde. Daar staat tegenover dat de invoering van een juridische beschermingsconstructie een statistisch significante, negatieve invloed heeft op de ondernemingswaarde.

\subsection{Anti-overnamehypothese}

Er zijn verschillende hypothesen denkbaar met betrekking tot de invloed van beschermingsconstructies op de waarde van een onderneming. Wij testen er in deze studie twee: de anti-overnamehypothese en de anti-disciplineringshypothese. De anti-overnamehypothese houdt in dat de onderneming zich wil afschermen tegen onvriendelijke overnames. In dit onderzoek zijn daartoe de (mogelijkheid tot uitgifte van) preferente aandelen, de prioriteitsaandelen, de zogenaamde $\mathrm{X} \%$ regeling en de certificering van gewone aandelen nader bekeken. Als gevolg van deze beschermingsconstructies lopen de nieuwe aandeelhouders een eventuele overnamepremie mis. Potentiële overnemers kunnen immers niets uitrichten zonder instemming van de raden van bestuur en commissarissen van de desbetreffende onderneming. De anti-overnamehypothese voorspelt dat de waarde van de emitterende instelling daalt, als een onderneming een of meer beschermingsconstructies geintroduceerd heeft. Dit is af te meten aan waardemaatstaven uit de jaarrekening, zoals de koers-winst verhouding en de koers-eigen vermogen verhouding. Omdat het mislopen van een eventuele overnamepremie in een efficiënte markt al in de koers verdisconteerd zal zijn, luidt de hypothese dat er geen invloed van de aanwezigheid van deze constructies op de ondernemingswaarde meer is na het moment van beursintroductie. Op het moment dat een anti-overnamecon- 
structie door een onderneming geïntroduceerd wordt. treedt er wel een daling van de ondernemingswaarde op. Zie bijvoorbeeld Cantrijn en Kabir (1992).

\subsection{Anti-disciplineringshypothese}

De lweede hypothese voor de annwezigheid van beschermingsconstructies is dat het management van de emittent zich wil afschermen tegen kritische atandeelhouders. Deze hypothese zullen we in het vervolg aanduiden met anti-disciplineringshypothese. De onderneming heeft door zijn beursgang nieuwe eigenaren gekregen. maar deze worden door beschermingsconstructies monddood gemaakt.

Zoals hicrvoor uiteengezet fungeert vooral het structuurregime als een effectief instrument om de invloed van aandeelhouders op de dagelijkse gang van zaken te minimaliseren. Anders gezegd: het structuurregime verhindert dat het management van de onderneming wordt blootgesteld ain de markt voor "corporate control'.

Aangezien het management continu beslissingen neemt. dic invloed hebben of zullen hebben op de ondernemingswararde, zullen andeelhouders er voortdurend aan herinnerd worden dat hun mening er weinig of niet toe doet.

De anti-disciplineringshypothese voorspelt een negatieve relatic lussen de walarde van een onderneming en de aanwezigheid van een anti-disciplineringsmechanisme.

\section{Ondernemingswaarde en structuurregime: de empirie}

\section{I Data}

De dala van het onderzoek komen uit de emissieprospectussen van alle ondernemingen die in de jaren 1983-1992 een eerste notering kregen op de Amsterdamse Elfectenbeurs. In total zijn in de bedoelde periode 74 bedrijven, die geen beleggingsmaatschappij of houdstermaatschappij zijn van een reeds aan een effectenbeurs genotcerde binnen- of buitenlandse onderneming, naar de beurs gegaan.

Het van toepassing zijn van het structuuregime kon worden bepaald aan de hand van de (uittreksels van de) statuten, die waren opgenomen in de prospectussen. Tabel 1 laal zien dat 31 ondernemingen ( $42 \%$ ) in het bezil waren van het structuurregime. Daarnalast werden door de emittenten andere beschermingsconstructies geïntroduceerd. De twee meest gebruikte beschermingsconstructies bij nieuw genoteerde bedrijven zijn de aanwezigheid van prioriteitsaandelen en de machtiging om prelerente aandelen uit te geven.

Door de tweedeling in bedrijven met en zonder structuurregime is voorkomen dat een grootteeffect bij de in dit onderzoek gehanteerde waardemaatstaven (zie paragraal 5.2 hierna) een rol zou spelen. Bedoelde waardemaatstaven zijn namelijk deels aflankelijk van de ondernemingsomvang.

\subsection{Methodologice}

De waarde van de uitgevende instelling is gemeten op verschillende momenten. De eerste bepaling betreft het moment van de beursgang. Hiertoe is gebruikgemaakt van walardematstaven ontleend aan informatie uit het jaarverslag van de emitterende instelling. dat onderdeel is van het emissieprospectus. Er zijn drie waardemaatstaven gehanteerd: de emissiekoers-winst per alandeel verhouding ( $\mathrm{P} / \mathrm{E}-\mathrm{rat}$ io), de emissiekoers-eigen vermogen per alandeel verhouding ( $\mathrm{P} / \mathrm{B}-\mathrm{ratio})$ en de emissiewaarde. het product van de emissiekoers en het aantal geplaatste aandelen na emissie. Het gebruik van de $\mathrm{P} / \mathrm{E}$-ratio en de $\mathrm{P} / \mathrm{B}$-ratio als maatstaf voor ondernemingswarde wordt door een reeks van publicaties ondersteund. Zie voor een overzicht van deze artikelen bijvoorbeeld Brouwer. Van der Put en Veld ( 1996). Deze auteurs hebben een empirisch onderzock over de periode 1982-1992 uitgevoerd naar de aandelenrendementen van ondernemingen genoteerd aan de beurzen van Duitsland, Frankrijk, Nederland en het Verenigd Koninkrijk. Zij vinden dat aandelenportefeuilles geselecteerd op onder meer de P/Een $\mathrm{P} / \mathrm{B}$-ratio buitengewone rendementen vertonen. die niet verklaard kunnen worden door verschillen in risico of grootle. Als reden noemen de auteurs dat beheerders van beleggingsfondsen makkelijker een mager rendement op een eerste klas aandeel kunnen verkopen alan hun cliënten dan een dito resultaat op een slecht aandeel.

Behalve de waardebepaling op het moment van beursintroductie met behulp van matatstaven afkomstig uit de jaarrekening is ook de koersontwikkeling op een aantal tijdstippen na beursintroductie onderzocht. Deze waardering is gebaseerd op marktrendementen. Hiertoe is als maatstal genomen het extra rendement van cen alandeel. Het extra rendement is de procentuele koersverandering van het aandeel op een bepaald tijdstip na de beursintroductie ten 
Tabel 3

\begin{tabular}{|c|c|c|c|c|c|c|}
\hline & \multicolumn{6}{|c|}{ In (Emissiewaarde) } \\
\hline & \multicolumn{3}{|c|}{$\begin{array}{l}\text { alleen ondernemingen met } \\
\text { structuuregime }(n=31)\end{array}$} & \multicolumn{3}{|c|}{$\begin{array}{c}\text { alleen ondernemingen zonder } \\
\text { structuuregime }(n=43)\end{array}$} \\
\hline & zonder ${ }^{r}$ & $m e t^{2}$ & & zonder $^{t}$ & $m e t^{2}$ & \\
\hline Prioriteitsaandelen & 4,86 & 4,43 & $(-0.65)$ & 5,26 & 3,96 & $(-3,23)^{* * *}$ \\
\hline Preferente aandelen & 4,18 & 5,21 & $(1,88)^{* *}$ & 4,39 & 4,30 & $(-0,21)$ \\
\hline Certificaten van gewone aandelen & 4,95 & 4,58 & $(-0.63)$ & 4,47 & 4,10 & $(-0,88)$ \\
\hline$X \%$-regel & 4,81 & 4,59 & $(-0,36)$ & 4,38 & 3,58 & $(-0,85)$ \\
\hline \multicolumn{7}{|c|}{ T-waarden tussen haakjes; $* * *=$ significant $1 \%$ niveau, $* *=$ significant op $10 \%$ niveau } \\
\hline \multicolumn{7}{|c|}{ Ln (Emissiewaarde) $=$ de natuurlijke logarithme van de emissiewaarde } \\
\hline \multicolumn{7}{|c|}{ Emissiewaarde $\quad=$ het product van het aantal geplaatste aandelen na beursintroductie en de emissiekoers } \\
\hline \multicolumn{7}{|c|}{ Emissiekoers $\quad=$ de prijs van het aandeel zoals vermeld in het emissieprospectus } \\
\hline \multicolumn{7}{|c|}{ 'zonder $\quad=$ emissiewaarde van ondernemingen zonder prioriteitsaandelen, preferente aandelen enz. } \\
\hline \multicolumn{7}{|c|}{$=$ emissiewaarde van ondernemingen met prioriteitsaandelen, preferente aandelen enz. } \\
\hline
\end{tabular}

Er is een sta tistisch significante, negatieve associatie tussen de aanwezigheid van prioriteitsaandelen en de natuurlijke logarithme van de emissiewaarde (t-waarde $=-3,23$ ). Dil duidt op een substitutie-effect tussen structuurregime en prioriteitsaandelen.

Er is een statistisch significante, positieve associatie tussen de mogelijkheid tot het uitgeven van preferente aandelen en de emissiewarde ( $t$-waarde $=1.88$ ) waneer een onderneming geen structuurregime bezit. Dit houdt in dat het structuurregime en preferente aandelen complementair zijn.

opzichte van zijn slotkoers op de eerste dag van verhandeling gecorrigeerd voor de koersontwikkeling van de Amsterdamse Effectenbeurs in zijn geheel met behulp van de CBS-koersindex. Door deze methodiek blijft de underpricing op de eerste dag van verhandeling buiten beschouwing. Zie voor een beschrijving van de hier bedoelde procentuele koersverandering de appendix.

\section{Resultaten}

\subsection{De effectiviteit van de beschermingscon- structies gebaseerd op informatie uit de jaarrekening}

Uit tabel 2 valt af te leiden dat het verband tussen elk van de drie maatstaven voor ondernemingswaarde en de machtiging tot plaatsing van preferente aandelen respectievelijk de X\%-regel geen enkele maal statistisch significant is. Dezelfde tabel laat zien dat het structuurregime twee maal, namelijk in geval van de $\mathrm{P} / \mathrm{E}$-ratio en de $\mathrm{P} / \mathrm{B}$-ratio, een statistisch significant en negatief verband heeft. Weliswaar is er in drie gevallen een statistisch significante relatie tussen de aanwezigheid van prioriteitsaandelen en de drie waardemaatstaven, maar deze relatie is niet eenduidig: het teken ervan is in twee gevallen positief en in één geval (voor de emissiewaarde) negatief. De certificering van gewone aandelen als beschermingsmaatregel heeft een statistische significantie die ligt tussen die van de $\mathrm{X} \%$-regel en de prioriteitsaandelen in. In één geval is er een statistisch significante, negatieve relatie tussen ondernemingswaarde gemeten via de $\mathrm{P} / \mathrm{B}$-ratio en de aanwezigheid van gecertificeerde aandelen. De resultaten van tabel 2 leiden tot de conclusie dat beschermingsconstructies in het algemeen een negatieve invloed hebben op de ondernemingswaarde gemeten aan de hand van verschillende waardemaatstaven. Enige terughoudendheid is echter op zijn plaats, omdat het gevonden verband niet in alle gevallen negatief is.

Daarom hebben wij onderzocht in hoeverre er sprake is van een onderlinge samenhang bij het gebruik van beschermingsconstructies door de onderzochte ondernemingen. Het valt immers te verwachten dat ondernemingen die een eigen vermogen hebben dat kleiner is dan 25 miljoen gulden en daardoor niet verplicht zijn de structuurregeling toe te passen, van andere beschermingsconstructies gebruik zullen maken.

Tabel 3 toont een statistisch significant, negatief verband tussen de emissiewaarde en de aanwezigheid van prioriteitsaandelen bij ondernemingen zonder structuurregime. Bij ondernemingen die in het bezit zijn van het structuurregime doet dit 
verschijnsel zich niet voor. Dit geeft an dat met name kleinere ondernemingen prioriteitsaandelen hanteren. Blijkbaar worden prioriteitsiandelen gebruikt door ondernemingen als substituut voor het structuurregime. Dit is terug te voeren op het in paragraal 4 genoemde verbod op bindende voordrachten voor commissarissen en bestuurders bij structuurvennootschappen. Verder is uit tabel 3 af ce leiden dat de machtiging om preferente andelen uit te geven statistisch significant vaker voorkomt bij grotere ondernemingen. die al in het bezil zijn van een structuurregime. Een mogelijke verklaring voor deze uitkomst is dat het structuurregime als bescherming niet volledig waterdicht is.

\subsection{De effectiviteit ran beschermings- constructies op basis ran maktrendementen}

De overwegend negatieve invloed op de ondernemingswalarde van het structuurregime blijkt niet alleen op het moment van de beursintroductic. Ook daarna is er een aanzienlijk verschil in rendement van het geïntroduceerde atandeel al naar gelang de aanwezigheid van het structuurregime. Tabel 4 toont een alantal regressies met het extra rendement als te verklaren variabele en het aantal beschermingsconstructies als verklarende variabele op verschillende tijdstippen na de beursintroductie. Het volgende model is geschat:

\section{Extra rendement $=1$ | Aantal beschermingscon-} structies]

De 74 ondernemingen zijn verdeeld in twee groepen. Eén groep valn 43 ondernemingen is niet in het bezil van een structuurregeling. De andere groep van 31 ondernemingen bezit wet hel structuurregime. Slechts zes valn de 74 ondernemingen gingen zonder beschermingsconstructies naar de beurs. Onderdeel A valn tabel 4 laal zien dat de relatie tussen het extra aandelenrendement van

Tabel 4

\begin{tabular}{|c|c|c|c|c|c|c|c|c|}
\hline \multicolumn{9}{|c|}{ Onderdeel $\lambda$ : Extra rendement ran ondernemingen Eonder structururegime $\left(n=t_{3}\right)$} \\
\hline Variabele & \multicolumn{2}{|c|}{ Evtra rendement ... } & \multicolumn{2}{|c|}{ Exra rendement sutunden } & \multicolumn{2}{|c|}{ Evtra rendement fMadunden } & \multicolumn{2}{|c|}{ Extra rendement resturatent } \\
\hline Intcrcept $\left(\alpha_{01}\right)$ & 1.10 & $(0.3 .3)$ & 4.22 & $(0.87)$ & 11.77 & $(1.05)$ & 9.17 & $(0.53)$ \\
\hline $\begin{array}{l}\text { Aantal beschermings- } \\
\text { constructics }(\alpha)\end{array}$ & -2.21 & $(-1.17)$ & $-3,26$ & $(-1.19)$ & $-7 .+0$ & $(-1.16)$ & -7.30 & $(-0,75)$ \\
\hline Gecorrigeerde $\mathrm{R}^{2}$ & \multicolumn{2}{|l|}{0.01} & \multicolumn{2}{|l|}{0.01} & \multicolumn{2}{|l|}{0.01} & \multicolumn{2}{|l|}{-0.10} \\
\hline F-waarde & \multicolumn{2}{|l|}{1.38} & \multicolumn{2}{|l|}{$1,+2$} & \multicolumn{2}{|l|}{1.36} & \multicolumn{2}{|l|}{0.56} \\
\hline \multicolumn{9}{|c|}{ Onderdeel B: Exwa rendement van ondernemingen met structumregine $(n=31)$} \\
\hline & \multicolumn{2}{|c|}{ Evra rendeme'nt, whand } & \multicolumn{2}{|c|}{ Evira rendement an } & \multicolumn{2}{|c|}{ Extra rendement nowasten } & \multicolumn{2}{|c|}{ Extra rendement rastanden } \\
\hline Intercept $\left(\alpha_{0}\right)$ & 5.16 & $(1.18)$ & 16.17 & $(2.20)^{* * *}$ & 36.12 & $(2.07)^{\text {非况 }}$ & $53.9+$ & $(1.85)^{*}$ \\
\hline constructies $(0 !)$ & -2.41 & $(-1.55)$ & -7.43 & $(-2.82)^{\text {* * * 水 }}$ & -12.77 & $(-2,06)^{* * *}$ & -18.66 & $(-1.77)^{*}$ \\
\hline Gecorrigeerde R: & 0,04 & & 0.19 & & 0.10 & & 0.10 & \\
\hline F-waliude & 2.39 & & 7.96 & $* * *$ & 4.25 & $* *$ & 3.15 & $*$ \\
\hline
\end{tabular}

Onderded A: Crosse-sectieregressies van hel extra rendement na beursgang en hel aantal beschemingsconsuructles op de Amsterdamse Eftectenbeurs over de periode 1983-1992. Allecn ondememingen zonder stlucturregime zijn in beschouwing genomen.

Onderdeel B: Idem als onderdeel A. Echer, nu zijn alleen ondernemingen met strucluurregime in beschouwing genomen.

Voor zowel onderdeel A als B luidt de regressievergelijking:

[Ex1ra rendement $]_{,}=\alpha_{11}+\alpha_{1} \mid$ A intal beschermingsconstructics $\mid+\epsilon$ walrin voor ondernemung $\mathrm{j}$

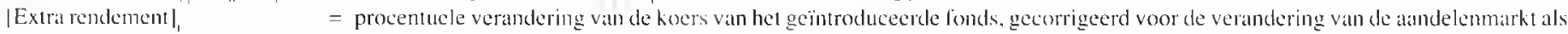
gehed met hehulp van de CBS-koersindex op tijdstip t

$=$ een tijdstip 1. 3.6 en I 2 mainden na de beursintroductie

Aantal beschermingsconstructies = wantal beschermungsconstructies pet onderneming: de variabele heelt een walarde van 0 . I. 2 , 3 ol 4

= een storingsterm

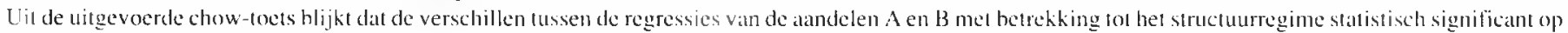

$1 \%$ niveau zijn. 
ondernemingen en het aantal beschermingsconstructies exclusief het structuurregime voor alle onderzochte tijdstippen weliswar negatief, maar statistisch niet significant is. Daartegenover stalat dat het verband tussen het extra rendement na beursgang van de ondernemingen en het aantal beschermingsconstructies inclusief het structuurregime (onderdeel B van tabel 4) wel statislisch significant en negatief is. Het extra rendement na één maind is als enige regressie in onderdeel $\mathrm{B}$ nict signilicant op het $10 \%$ niveau, maar wel negatief ( 1 -waarde -1.55 ). Een verklaring voor het laatste verschijnsel zou kunnen zijn dat in een atuntal gevallen de syndicaatsleider gedurende de eerste dertig dagen na de beursintroductie activiteiten ontplooit om de koers te stabiliseren.

Het volgende getallenvoorbeeld op basis van cén van de regressies uit onderdeel B van tabel 4 (zie pag. 51.3) illustreert de negatieve invloed van beschermingsconstructies op de ondernemingswaarde. Het extra rendement zes maanden na de beursintroductie bedragat voor cen onderneming - zonder beschermingsconstructie:

$$
36.12-0 \times 12.77=36.12 \%
$$

- met één beschermingsconstructie:

$$
36.12-1 \times 12.77=23,35 \%
$$

- mel twee beschermingsconstructies:

$$
36.12-2 \times 12.77=10.58 \% \text { enz. }
$$

Met andere woorden: het extra rendement neemt af narmate een onderneming meer beschermingsconstructies heeft.

\section{Samenvatting en conclusies}

Beschermingsconstructies zijn er in soorten en maten. In deze bijdrage is allereerst onderscheid gemaakt tussen economische en juridische beschermingsconstructies. Een cruciaal verschil lussen beide is dat de eerste categorie gepalard gaat met betalingen en de tweede niet. Invoering van economische beschermingsconstructies lijkt geen effect te hebben op de ondernemingswaarde. Immers, een economische beschermingsconstructie wordt verkregen in ruil voor een feitelijke betaling van de betrokken onderneming. Een juridische beschermingsconstructie darentegen wordt zonder enige (geldelijke) tegenprestatic verkregen.

Het tweede onderscheid betreft de verschillende functies en effecten van beschermingsconstructies: enerzijds de bescherming tegen een vijandige overname, anderzijds de verschuiving in machtsverhoudingen binnen de onderneming en daarmee het wegvallen valn de mogelijkhcid voor aandeelhouders om het management te disciplineren. Dit onderscheid is in het bijzonder relevant bij een nadere besclouwing van de structuurregeling: oorspronkelijk bedoeld als een verschuiving in de machısbalans in grote vennootschappen ten nadele van de algemene vergadering van aandeelhouders met als onbedoeld neveneffect de bescherming tegen een vijandige overname. In dit artikel is geprobeerd de verschillende constructies zodanig te rangschikken dat recht wordt gedaan aan de meerdimensionaliteit van beschermingsconstructies.

Deze indeling is startpunt voor de empirische toetsing van de twee hypothesen over het effect van de constructies op de ondernemingswarde. Het datamateriaal wordı gevormd door de 74 ondernemingen die in de periode 1983 tot en met 1992 een eerste notering kregen op de Amsterdimse Effectenbeurs.

Zoals tabel 2 laat zien. hebben de mogelijkheid tor uitgifte van preferente aandelen en de aunwezigheid van de X\%-regeling bij certificering geen significant verband met de ondernemingswaarde. Diar staat legenover dat er wel een statistisch significant, negatief verband bestaat tussen het structuurregime en de drie gekozen maatstaven voor de ondernemingswalarde met uitzondering van de associatie tussen de emissiewiarde en de structuurregeling.

Het verband tussen ondernemingswarde en maatstaven gebaseerd op informatie uit de jaarrekening is niet eenduidig. De regressies van tabel 4 laten wèl een eenduidig verband zien tussen het extra rendement en het aantal beschermingsconstructies: alle regressiecoëfficiënten hebben een negatief teken. Bovendien is er in tabel 4 onderdeel $B$ sprake van een overwegende negaticve invloed van het structuurregime op het extra rendement met uitzondering van de eerste maand na de beursintroductie. Gezien de uitkomsten van onderdeel B van tabel 4 lijkt het erop dat beleggers zich pas na de beursintroductie de effecten van de structuurregeling realiseren. Tot één jaar na de beursintroductie is er immers nog cen statistisch significante, negatieve invloed van het structuurregime op het alandelenrendement te constateren. Met betrekking tot dit aspect kan dan ook van een niet-efficiënte aandelenmarkt gesproken worden.

De uitkomsten van de studie zouden een aanwijzing kunnen zijn voor de stelling dat vooral 
constructies die de invloed van aandeelhouders permanent aan banden leggen (de anti-disciplineringsmechanismen) een negatief effect hebben op de ondememingswaarde en dat zo"n effect bij specifieke en algemeen bekende anti-overnameconstructies niet 1ot uiting komt in de aandelenrendementen, omdat het laatste eflect al in de emissiekoers verdisconteerd is. 'Gratis' verkregen juridische beschermingsconstructies brengen uiteindelijk wèl kosten met zich mee. Dit zijn opportunity kosten in de vorm van een lager extral rendement ten opzichte van ondernemingen zonder juridische beschermingsconstructies.

Dit onderzoek loont aan dat het structuurregime zowel als anti-ovemame-als anti-disciplineringsconstructie hoog scoort. Het is vooral het systeem van gecontroleerde coöptatie wat onder vuur ligt, omdat het zou leiden tot gebrek aan disciplinering van het management. Een nadere bezinning om het structuuregime in zijn huidige vorn te handhaven lijkı ons dan ook op zijn platats. De oplossing zou gezocht moeten worden in het (deels) ontkoppelen van de twee hiervoor genoemde eigenschappen, bijvoorbeeld door directe benoeming van (of een bindende voordrachl voor) een deel van de commissarissen door direct belanghebbenden en coöptatie van de overige commissarissen. Een van de voordelen van een wijziging in die richling is dat de verschillende eflecten die hel structuurregime nu heeft zowel het ondergraven van de disciplinering van het management als bescherming tegen een vijandige overval - als hel ware uit elkaar worden getrokken: wel (toename van) de disciplinering van het management onder behoud van het beschermingskarakter (los van de vraag of dat laatste als wenselijk wordt beschouwd).

Een van de onderwerpen voor verder onderzoek zou kunnen zijn in welke mate beschermingsconstructies en in het bijzonder de structuurregeling. invloed hebben op de waarde van reeds genotcerde ondernemingen. Hel laatste onderzoek zou antwoord moeten geven op de vralag of de uitkomsten van de onderhavige studie gelden voor alle beursgenoteerde ondernemingen.

\section{Appendix}

Het extra rendement van hel geintroduceerde aandeel is bepaald volgens onderstande formule. Door de koersontwikkeling te bepalen ten opzichte valn de slotkoers van het geintroduceerde fonds op de eerste dag van verhandeling is de underpricing geen onderdeel van het exira rendement.

$E R_{1,1}=\frac{P_{1,1}-P_{1,1}}{P_{t, 1}}-\frac{\text { Index }- \text { Index }}{\text { Index }}$

waarin voor onderneming j.

ER = extra rendement: dit is de voor de aandelenmarktontwikkeling gecorrigeerde koersontwikkeling van het geintroduceerde aandeel op tijdstip t

$\mathrm{P}_{1} \quad=$ de slotkoers van het geïntroduceerde alandeel op tijdstip t

$\mathrm{P}_{\mid} \quad=$ de slotkoers van het geintroduceerde aandee] op de eerste handelsdag

Index $_{1}=$ de waarde valn de CBS-koersindex op de eerste handelsdag

Index $_{1}=$ de waarde van de CBS-koersindex op tijdstip t

$1=$ tijdstip $1,3,6$ en 12 maanden nal beursintroduclie

De CBS-koersindex word eenmaal per dag berekend als het met de markı warde van alle fondsen gewogen gemiddelde van de slotkoersen van de betreffende handelsdag.

\section{ITERAT U U R}

Boot, A.W.A., (1994), Corporate governance, structuurregime en de financiering van het bedrijfsleven, Maandblad voor Accountancy en Bedrifseconomie, pp. 724-736.

Bosveld, R. en Goedbloed, A.M., (1996), Effecten van beschermingsconstructies op aandeelkoersen, Maandblad voor Accountancy en Bedriffeconomie, pp. 261-270.

Brouwer, I., Van der Put, J., and Veld, C., (1996), Contrarian investment strategies in a European context, working paper van het Center for Economic Research, Katholieke Universiteit Brabant, pp. 1-19

Cantrijn, A.L.R. en Kabir, M.R., (1992), De invloed van preferente beschermingsaandelen op aandelenkoersen, Maandblad voor Accountancy en Bedriffseconomie, pp. 328-340.

Commissie Corporate Governance (Commissie Peters), (1997), Aanbevelingen inzake Corporate Governance in Nederland, Vereniging voor de Effectenhandel, juni, pp. 1-48. Hoek, P.C. van den, (1995), 'Structuurregeling', in: Knelpunten in de vennootschapswetgeving, Uitgaven vanwege het 
Instituut voor Ondernemingsrecht Rijksuniversiteit Groningen deel 24, Deventer: Kluwer, pp. 35-51.

Jarrell, G.A. en Poulsen, A.B., (1987), Shark repellents and stock prices, the effects of antitakeover amendments since 1980, Journal of Financial Economics, pp. 127-168.

Ministerie van Financiën, (1996), Brief aan de Tweede Kamer over Beschermingsconstructies ((br 28-2-'96), februari, pp. 1-5.

\section{N O T E N}

1 Onze dank gaat uit naar Prof. Dr. P.H. Wallage RA en leden van de redactie van dit blad voor commentaar en suggesties. Wij alleen zijn verantwoordelijk voor de inhoud van het stuk. Sommige stukken van dit artikel maken deel uit van het proefschrift van L.R.T. van der Goot waarop hij op 3 sep- tember 1997 is gepromoveerd. De titel van de dissertatie is 'Valuing New Issues, Information Quality of Initial Public Offerings at the Amsterdam Stock Exchange' (uitgegeven bij Thesis Publishers te Amsterdam).

2 Zie P.C. van den Hoek, 'Structuurregeling', in: Knelpunten in de vennootschapswetgeving, Uitgaven vanwege het Instituut voor Ondernemingsrecht Rijksuniversiteit Groningen deel 24, Deventer: Kluwer 1995, pp. 35-51, in het bijzonder pp. 39-40 alsmede A.L. Mohr, 'De rol van de Ondernemingskamer in het kader van de problematiek rond beschermingsconstructies en betwiste overnames', 25 jaar ondernemingskamer, Den Haag: Sdu, 1995, pp. 91-113.

3 Zie Van den Hoek, t.a.p.

4 Denk aan de statutaire bepaling dat een voorstel tot statutenwijziging slechts kan worden ingediend door het bestuur en/of de raad van commissarissen.

5 Zie artikel 2:133 BW en 2:243 BW.

6 Zie artikel 2:133 lid 2 BW. 